IIIIIIIIIIIIIIIIIIIIIIIIIIIIIIIIIIII

Original Article

IIIIIIIIIIIIIIIIIIIIIIIIIIIIIIIIII

\title{
A bioassay evaluation of pyroxasulfone behavior in prairie soils
}

\author{
Anna M. Szmigielski, ${ }^{1, *}$ Eric N. Johnson ${ }^{2}$ and Jeff J. Schoenau ${ }^{1}$ \\ ${ }^{1}$ Department of Soil Science, University of Saskatchewan, Saskatoon, SK S7N 5A8, Canada \\ ${ }^{2}$ Agriculture and Agri-Food Canada, Research Farm, Scott, SK SOK 4A0, Canada
}

(Received November 7, 2013; Accepted December 21, 2013)

\begin{abstract}
Pyroxasulfone behavior in prairie soils was evaluated using a 7-day sugar beet (Beta vulgaris L.) shoot length inhibition bioassay. Pyroxasulfone bioactivity in soil, assessed from 0 to $184 \mathrm{ga}$ a. $/ \mathrm{kg}$, was primarily related to organic carbon content $(p=0.001)$ with decreased bioactivity occurring in soils of high organic carbon. Pyroxasulfone bioactivity, measured after soil pH adjustments, was reduced as soil $\mathrm{pH}$ decreased demonstrating that at low soil $\mathrm{pH}$ pyroxasulfone becomes less available to plants. Pyroxasulfone half-lives estimated for dissipation at $25^{\circ} \mathrm{C}$ and moisture content of $85 \%$ field capacity ranged from 16 to 69 days. Organic carbon content $(p=0.034)$ and soil $\mathrm{pH}(p=0.008)$ were significant in affecting pyroxasulfone half-lives with faster dissipation occurring in soils of high organic carbon content and high $\mathrm{pH}$. Interactions between soil-incorporated pyroxasulfone and sulfentrazone were either antagonistic or additive and the nature of these interactions could vary with soil type. () Pesticide Science Society of Japan
\end{abstract}

Keywords: pyroxasulfone, bioassay, bioactivity, dissipation, $\mathrm{pH}$, interactions.

\section{Introduction}

Pyroxasulfone is a novel pre-emergence herbicide that is efficacious against annual grasses and small-seeded broadleaf weeds, and is used primarily for weed control in corn (Zea mays L.), wheat (Triticum aestivum L.), soybean (Glysine max L.), and other crops such as sunflower (Helianthus annuus L.). ${ }^{1-6)}$ Pyroxasulfone is classified as Group 15 herbicide by the Weed Science Society of America and as Group K3 herbicide by the Herbicide Resistance Action Committee. Pyroxasulfone is considered to be a seedling shoot growth inhibitor and the primary target enzyme is very long chain fatty acid elongase. It inhibits several fatty acid elongation steps for shoot formation and cell proliferation in the plants. ${ }^{7)}$

Pyroxasulfone (3-[(5-(difluoromethoxy)-1-methyl-3(trifluoromethyl)pyrazol-4-ylmethylsulfonyl]-4,5-dih ydro-5,5-dimethyl-1,2-oxazole) (Fig. 1) has the following selected physical properties: water solubility at $20^{\circ} \mathrm{C}=$ $3.49 \mathrm{mg} / \mathrm{L}, \log K_{\mathrm{OW}}=2.39$, Henry's law constant at $20^{\circ} \mathrm{C}=$ $2.65 \times 10^{-9} \mathrm{~atm} \mathrm{~m}^{3} / \mathrm{mol}$. Pyroxasulfone molecule does not ionize as it does not have a dissociable moiety (Fig. 1). ${ }^{5,8)}$

Typically, recommended pyroxasulfone field application rates depend on soil texture and organic matter content, and are higher in soils of high clay and high organic matter content. ${ }^{1,4,5,8-10)}$ In Ontario (Canada) where pyroxasulfone is registered for weed

\footnotetext{
* To whom correspondence should be addressed.

E-mail: anna.szmigielski@usask.ca

Published online February 8, 2014

(C) Pesticide Science Society of Japan
}

control in corn, the field application rates are $123 \mathrm{ga}$.i./ha on coarse (sandy) soil, 166 and $208 \mathrm{~g}$ a.i./ha on medium to mediumfine soil with organic matter content $\leq 3 \%$ and $>3 \%$, respectively, and $247 \mathrm{~g}$ a.i./ha on fine-textured (high clay content) soil. ${ }^{8)}$ Pyroxasulfone may not provide complete control of some weeds and may require use of sequential herbicide applications or use of tank mixtures or premixed formulations with other herbicides such as atrazine, ${ }^{2,8,11)}$ glyphosate, ${ }^{8,12)}$ flumioxazin, ${ }^{5)}$ fluthiacetmethyl, ${ }^{9)}$ or atrazine plus fluthiacet-methyl. ${ }^{10)}$ Moisture is necessary to activate pyroxasulfone in soil and dry weather following application may reduce effectiveness. However, when adequate moisture is received after dry conditions, pyroxasulfone will control susceptible germinating weeds. ${ }^{9)}$ Pyroxasulfone has residual properties and enables control of weeds emerging later in the season. The reported dissipation half-lives are in the range from 4 to 35 days, ${ }^{8)}$ however, because pyroxasulfone may persist in soil to the next growing season, herbicides containing pyroxasulfone alone and premixed formulations containing pyroxasulfone have 18-month rotation restriction to all crops except corn, soybean and wheat. ${ }^{8,9)}$

Because pyroxasulfone mode of action is distinctly differ-

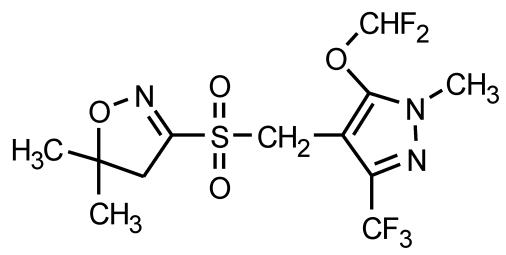

Fig. 1. Chemical structure of pyroxasulfone. 
ent from the mode of action of many commonly used herbicides such as triazines, sulfonylureas and imidazolinones to which weeds developed resistance, it provides a new alternative in combating the weed resistance problems. ${ }^{5)}$ By using pyroxasulfone in rotation ${ }^{4,12)}$ or in combination with other herbicides ${ }^{2,6,11-13)}$ the efficacy of weed control is improved and the likelihood of weeds developing resistance may be decreased or delayed.

Crop tolerance trials conducted in western Canada have indicated that spring wheat, winter wheat, and field pea (Pisum sativum L.) exhibit acceptable tolerance to pyroxasulfone, while weed control efficacy trials have shown consistent control of Bromus spp. and suppression to control of Galium spp. and wild oat (Avena fatua L.). ${ }^{14)}$ Since pyroxasulfone will become available in western Canada for use in wheat production in the near future, the evaluation of pyroxsulfone behavior in Canadian prairie soils with a suitable bioassay is needed. Plant bioassays are a useful tool in research and in soil testing because they detect the actual bioavailable amount of herbicide in soil, while chemical techniques are suitable for determination of total herbicide present in soil. Despite some disadvantages, such as lack of specificity and variability in response with plant species and soil type, bioassays are generally very sensitive and detect amounts of herbicides available to sensitive plants at low concentrations. Because pyroxasulfone is a relatively new herbicide, no bioassay technique has been proposed for the detection of its residues in soil. The objectives of this study were (1) to develop a plant bioassay for detection of pyroxasulfone in soil, (2) to investigate pyroxasulfone bioactivity in soil, (3) to evaluate the effect of soil $\mathrm{pH}$ on pyroxasulfone bioactivity, (4) to assess pyroxasulfone dissipation in soil, and (5) to examine pyroxasulfone interactions with sulfentrazone.

\section{Materials and Methods}

\section{Soils}

Five soils typical of the Canadian prairies were collected in Saskatchewan from the 0 to $10 \mathrm{~cm}$ depth, air-dried at room temperature and passed through a $2-\mathrm{mm}$ sieve. Selected soil properties are listed in Table 1. Soil organic carbon was determined using a Leco CR-12 Automated Combustion Carbon Determinator at $840^{\circ} \mathrm{C}$ (Leco Corporation, St. Joseph, MI). Soil textures were assessed using a Horiba Laser Scattering Particle Size Distribution Analyzer (Horiba Instruments, Irvine, CA). Soil pH was mea- sured in a $1: 2$ soil: water suspensions, and field-capacity water content was estimated by determining the volume of water required to completely wet the air-dried soil to the bottom of a plastic vial.

\section{Chemicals}

A commercial formulation KIH-485 (FMC Corporation-Innovation Center, Ewing, NJ) that contains $85 \%$ pyroxasulfone was used for solution preparation. Assuming that applied pyroxasulfone remains in the top $10 \mathrm{~cm}$ of soil and a soil bulk density of $1.3 \mathrm{~g} / \mathrm{cm}^{3}$, a field application rate of $120 \mathrm{~g}$ a.i./ha was determined to be equivalent to $92 \mu \mathrm{g}$ a.i./kg dry soil. Pyroxasulfone stock solution was prepared by dissolving $0.108 \mathrm{~g} \mathrm{KIH}-485$ in $1 \mathrm{~L}$ of water:acetone mixture ( $4: 1$ by volume) yielding a pyroxasulfone concentration of $92 \mathrm{mga}$ a. /L. Through further dilutions with water, a series of solutions containing pyroxasulfone at concentration of $0,2.3,4.6,6.9,9.2,13.8$ and $18.4 \mathrm{mg}$ a.i./L was prepared. A $0.5-\mathrm{mL}$ volume of each pyroxasulfone solution was combined with the volume of distilled water equivalent to $100 \%$ moisture content at field capacity and was added to $50 \mathrm{~g}$ of airdried soil, yielding a pyroxasulfone concentration in the soil of $0,23,46,69,92,138$ and $184 \mu \mathrm{g}$ a.i./kg.

\section{Bioassay conditions}

After adding pyroxasulfone and water to the soil, soil was handmixed and transferred to 2-oz WhirlPak ${ }^{\circledR}$ bag (VWR International, Mississauga, ON, Canada). Soil in the bag was gently packed to form a layer approximately $8 \mathrm{~cm}$ high, $6 \mathrm{~cm}$ long and $1 \mathrm{~cm}$ wide. Six seeds of the desired bioassay plant species were planted at a 2-mm depth and the soil surface was covered with a 5-mm layer of plastic beads to reduce soil drying. ${ }^{15)}$ Plants were grown in the laboratory under fluorescent lights that had photosynthetic photon flux density of $16 \mu \mathrm{mol} / \mathrm{m}^{2} / \mathrm{s}$ at the plant level, and plants were watered daily to $100 \%$ field capacity by adding water to a predetermined weight. At harvest time, intact plants were recovered from soil after the WhirlPak ${ }^{\circledR}$ bag was opened and soil was washed away with water. Shoot and root lengths were measured with a ruler and percent shoot or root length inhibition was calculated using the formula ${ }^{16)}$ :

$$
\text { Inhibition }(\%)=100-\% \text { of control }=\left(1-\mathrm{L}_{\mathrm{t}} / \mathrm{L}_{0}\right) \times 100 \%
$$

where $\mathrm{L}_{\mathrm{t}}$ is the shoot or root length measured in the herbicidetreated soil and $\mathrm{L}_{0}$ is the shoot or root length in the untreated

Table 1. Selected characteristics of soils used in this study

\begin{tabular}{|c|c|c|c|c|c|c|}
\hline Soil (location) & Soil series & $\mathrm{OC}^{a)}(\%)$ & $\mathrm{pH}^{b)}$ & Sand $^{c)}(\%)$ & Clay $^{c)}(\%)$ & $\mathrm{FC}^{d)}(\%)$ \\
\hline Central Butte (1) & Haverhill loam & 1.3 & 7.9 & 52 & 23 & 14 \\
\hline Scott (1) & Scott loam & 2.0 & 5.0 & 43 & 19 & 18 \\
\hline Central Butte (2) & Haverhill clay loam & 2.2 & 7.2 & 28 & 38 & 18 \\
\hline Saskatoon & Sutherland clay & 3.2 & 7.8 & 14 & 60 & 28 \\
\hline Scott (2) & Weyburn loam & 3.2 & 6.2 & 35 & 22 & 22 \\
\hline
\end{tabular}

${ }^{a)} \mathrm{OC}$, organic carbon content. ${ }^{b)} \mathrm{pH}$ measured in a $1: 2$ soil: $\mathrm{H}_{2} \mathrm{O}$ suspension. ${ }^{c}$ Textural classes are defined in size distribution as clay $<0.002 \mathrm{~mm}$, silt $0.002-0.05 \mathrm{~mm}$, sand $>0.05 \mathrm{~mm}$, according to Canadian System of Soil Classification 3rd edition. ${ }^{d}$ FC, moisture content at field capacity. 
soil.

\section{Plant selection for the bioassay}

To identify a suitable plant species and a plant parameter for the detection of pyroxasulfone in soil, shoot and root reduction of sugar beet (Beta vulgaris L. 'Beta 1385'), canola (Brassica napus L. 'Invigor' 5770) and oriental mustard (Brassica juncea L. 'Cutlass') were measured in response to soil-incorporated pyroxasulfone at $92 \mu \mathrm{g}$ a.i. $/ \mathrm{kg}$, and were compared to shoot and root length obtained in the untreated soil after 4 days of growth in the Haverhill loam soil (Table 1).

To enhance plant response to pyroxasulfone, sugar beet was then grown for increasing number of days up to 8 days in the pyroxasulfone-treated soil at $92 \mu \mathrm{g}$ a.i. $/ \mathrm{kg}$, and in the untreated soil, and percent shoot and root inhibition was determined for each growth period.

\section{Pyroxasulfone bioactivity in soil}

To examine pyroxasulfone bioactivity in soil, five soils of varying properties were used (Table 1). Pyroxasulfone was added to soil in the range from 0 to $184 \mu \mathrm{g}$ a.i./kg (approximately equivalent to a field application rate from 0 to $240 \mathrm{~g}$ a.i./ha) and the 7 -day sugar beet shoot length bioassay was applied. Dose-response curves were obtained by graphing shoot length inhibition data $v s$. pyroxasulfone concentration using the log-logistic model ${ }^{17)}$ :

$$
\% \text { of control }=\mathrm{C}+(\mathrm{D}-\mathrm{C}) /\left(1+\left[\mathrm{x} / \mathrm{GR}_{50}\right]^{\mathrm{b}}\right)
$$

where $\mathrm{C}=$ lower limit of the curve, $\mathrm{D}=$ upper limit of the curve, $b=$ slope of the curve around $G_{50}$ value, and $\mathrm{GR}_{50}=$ concentration corresponding to $50 \%$ inhibition. Pyroxasulfone concentration required for 50\% shoot length inhibition $\left(\mathrm{GR}_{50}\right.$ value) was determined from the dose-response curves for each soil.

\section{Modification of soil $\mathrm{pH}$}

To assess the effect of soil $\mathrm{pH}$ on pyroxasulfone bioactivity, soil $\mathrm{pH}$ was altered to produce values either above or below natural $\mathrm{pH}$ values. In Haverhill clay loam and Scott loam (Table 1), soil $\mathrm{pH}$ was increased by adding a suspension of $0.2 \mathrm{~g} \mathrm{CaCO}_{3}$ per $50 \mathrm{~g}$ soil in a volume of water equivalent to $100 \%$ field capacity, and soil $\mathrm{pH}$ was lowered using $0.5 \mathrm{~mL}$ of $1 \mathrm{M} \mathrm{HCl}$ solution per $50 \mathrm{~g}$ soil added to soil with a volume of water equivalent to $100 \%$ field capacity. In Haverhill loam (Table 1), the addition of $\mathrm{CaCO}_{3}$ did not raise soil $\mathrm{pH}$, as this soil was calcareous to begin with, and to produce a range of soil $\mathrm{pH}$ values, the $\mathrm{pH}$ in this soil was lowered using $0.5 \mathrm{~mL}$ and $1 \mathrm{~mL}$ of $1 \mathrm{M} \mathrm{HCl} \mathrm{solu-}$ tion per $50 \mathrm{~g}$ of soil. After acid or base addition, soils in plastic containers were hand-mixed, covered, and allowed to equilibrate for 1 week. Soils were then air-dried, sieved $(2 \mathrm{~mm})$, and $\mathrm{pH}$ was determined. Soils with altered $\mathrm{pH}$ were then supplemented with pyroxasulfone in the range from 0 to $184 \mu \mathrm{g}$ a.i. $/ \mathrm{kg}$ and shoot length of sugar beet was measured in response to pyroxasulfone after 7 days of growth. Dose-response curves were obtained for each soil pH using Eq. 2.
7. Pyroxasulfone dissipation under laboratory conditions For the dissipation study, soils were prepared by adding pyroxasulfone at $92 \mu \mathrm{g}$ a.i./kg to Haverhill loam, Scott loam and Haverhill clay loam, and at $138 \mu$ ga.i./kg to Sutherland clay and Weyburn loam (Table 1). A $0.5-\mathrm{mL}$ volume of either 0.092 or $0.138 \mathrm{mg}$ a.i./L pyroxasulfone standard solution and a volume of water equivalent to $85 \%$ field capacity were added to $50 \mathrm{-g}$ soil portions in Styrofoam cups. Soils were hand-mixed, cups were capped with lids and placed in an incubator set at $25^{\circ} \mathrm{C}$. Soils were watered every other day to predetermined weight to bring soil moisture content back to $85 \%$ field capacity. Soils were sampled every two weeks up to 16 weeks after treatment. At each sampling, soils were air-dried, sieved, and residual pyroxasulfone was determined by the 7-day sugar beet shoot biossay. Pyroxasulfone half-life $\left(\mathrm{T}_{1 / 2}\right)$ in each soil was estimated from the dissipation curves after fitting the data to a first order decay $\operatorname{model}^{18)}$ :

$$
\mathrm{C}=\mathrm{C}_{0} \mathrm{e}^{-k \mathrm{~T}}
$$

where $\mathrm{C}=$ herbicide concentration remaining in soil after time $\mathrm{T}$, $\mathrm{C}_{0}=$ initial herbicide concentration, $k=$ dissipation rate constant.

\section{Pyroxasulfone and sulfentrazone interactions}

To examine interactions between soil-incorporated pyroxasulfone and sulfentrazone, the combined effect of these two herbicides on sugar beet shoot length inhibition was evaluated in Haverhill loam and Haverhill clay loam soils (Table 1). Soils were supplemented with combinations of pyroxasulfone in the range from 0 to $184 \mu \mathrm{g}$ a.i./kg with sulfentrazone added at 25 and at $50 \mu$ a.i./kg level in Haverhill loam and in Haverhill clay loam, respectively. These quantities of added sulfentrazone were approximately equal to the sulfentrazone $\mathrm{GR}_{50}$ values obtained from the sulfentrazone dose-response curves for these two soils. ${ }^{19)}$ Observed shoot length inhibition was determined using shoot length of sugar beet that was measured in response to combinations of pyroxasulfone and sulfentrazone. Expected shoot length inhibition was calculated using Colby's formula ${ }^{20)}$ :

$$
\mathrm{E}=\mathrm{X}+\mathrm{Y}-\mathrm{XY} / 100
$$

where $\mathrm{X}$ is the plant growth inhibition (\%) due to compound $\mathrm{A}$, and $\mathrm{Y}$ is the plant inhibition due to compound B. Dose-response curves were constructed for the observed and expected shoot length inhibition using Eq. 2, and the observed and expected inhibition values for each combination of pyroxasulfone and sulfentrazone were compared by a $t$-test in order to determine the nature of the interaction between these two herbicides. Herbicide interactions may be synergistic, antagonistic or additive depending on whether the combined effect on the target plant is greater, less than or equal to the summed effect of the herbicides applied alone. ${ }^{20,21)}$

All experiments were replicated four times and repeated as two independent runs. The data from two runs in each experiment were combined. Dose-response curves (Eq. 2) from which $\mathrm{GR}_{50}$ values were estimated and dissipation curves (Eq. 3) from 
which half-lives were determined were obtained after fitting the data to nonlinear regressions using Sigma Plot (Sigma Plot, San Rafael, CA). Multiple regression analysis of $\mathrm{GR}_{50}$ values and dissipation half-lives $v s$. organic carbon content (\%), soil $\mathrm{pH}$ and clay content (\%) was performed using Excel (Microsoft Corporation, Redmond, WA).

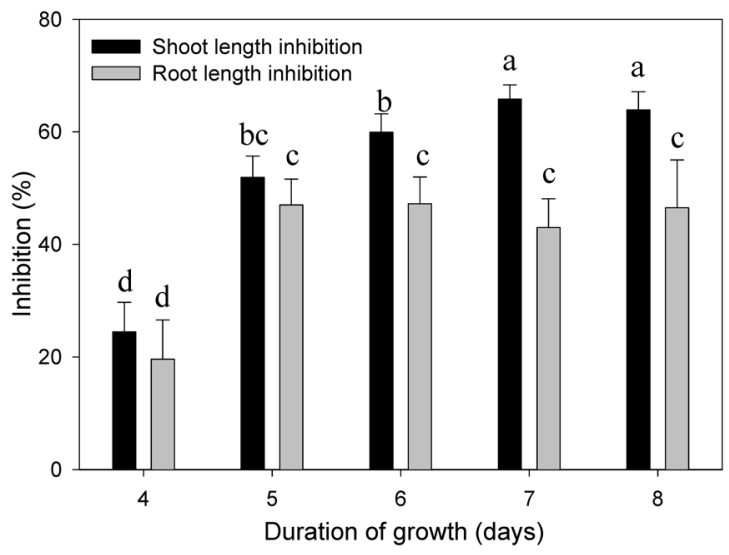

Fig. 2. Shoot and root length inhibition of sugar beet grown from 4 to 8 days in response to $92 \mu \mathrm{g}$ a.i. $/ \mathrm{kg}$ pyroxasulfone in the Haverhill loam soil (each data point represents mean \pm standard deviation; bars with the same letters are not different at 0.05 significance level).

\section{Results and Discussion}

\section{Development of a laboratory bioassay}

After 4 days of growth, sugar beet, canola and oriental mustard showed a relatively small and comparable inhibition due to added pyroxasulfone at $92 \mu \mathrm{g}$ a.i./kg. The percent inhibition (mean \pm S.D.) of shoot length was $24.5 \pm 5.2,25.8 \pm 9.9$ and $24.0 \pm 12.2$, and of root length was $19.6 \pm 7.0,18.9 \pm 9.8$ and $22.8 \pm 14.2$ for sugar beet, canola and oriental mustard, respec-

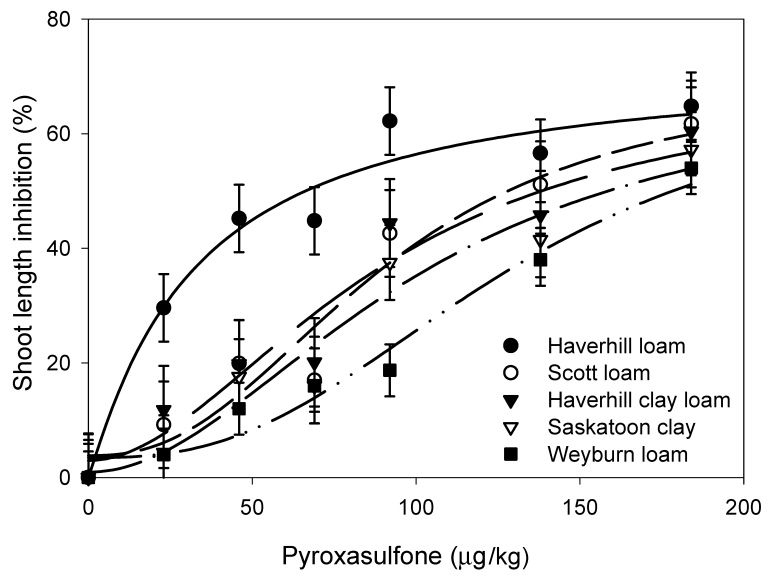

Fig. 3. Pyroxasulfone dose-response curves in prairie soils determined by the 7-day sugar beet shoot length bioassay; each data point represents mean \pm standard error; estimated equations are listed in Table 2.

Table 2. Estimated equations for pyroxasulfone dose-response curves obtained by fitting the data from the 7-day sugar beet shoot length bioassay to Eq. 2

\begin{tabular}{|c|c|c|}
\hline Soil & Equation & $\mathrm{R}^{2}$ \\
\hline \multicolumn{3}{|l|}{ Figure 3} \\
\hline Haverhill loam & $y=26.8+73.2 /\left(1+[x / 32.5]^{1.1}\right.$ & 0.966 \\
\hline Scott loam & $y=30.0+66.2 /\left(1+[x / 90.7]^{2.4}\right.$ & 0.946 \\
\hline Haverhill clay loam & $y=29.8+67.3 /\left(1+[x / 88.6]^{1.9}\right.$ & 0.937 \\
\hline Sutherland clay & $y=30.0+69.1 /\left(1+[x / 100.8]^{2.0}\right.$ & 0.952 \\
\hline Weyburn loam & $y=30.3+66.5 /\left(1+[x / 130.0]^{2.7}\right.$ & 0.972 \\
\hline \multicolumn{3}{|l|}{ Figure 4} \\
\hline Haverhill loam pH 7.9 (natural) & $y=26.8+73.2 /\left(1+[x / 32.5]^{1.1}\right.$ & 0.966 \\
\hline $\mathrm{pH} 7.6$ & $\mathrm{y}=25.1+78.9 /\left(1+[\mathrm{x} / 62.2]^{0.9}\right.$ & 0.902 \\
\hline $\mathrm{pH} 7.4$ & $y=27.0+66.6 /\left(1+[x / 103.5]^{0.9}\right.$ & 0.853 \\
\hline Haverhill clay loam pH 7.4 & $y=29.5+69.1 /\left(1+[x / 63.8]^{1.6}\right.$ & 0.973 \\
\hline pH 7.2 (natural) & $y=29.8+67.3 /\left(1+[x / 88.6]^{1.9}\right.$ & 0.937 \\
\hline pH 4.8 & $y=30.0+66.1 /\left(1+[x / 137.4]^{2.3}\right.$ & 0.937 \\
\hline Scott loam pH 6.4 & $y=24.1+75.6 /\left(1+[x / 98.9]^{1.5}\right.$ & 0.979 \\
\hline pH 5.0 (natural) & $y=30.0+66.2 /\left(1+[x / 90.7]^{2.4}\right.$ & 0.946 \\
\hline $\mathrm{pH} 4.3$ & $y=49.9+49.1 /\left(1+[x / 237.5]^{1.3}\right.$ & 0.861 \\
\hline \multicolumn{3}{|l|}{ Figure 5} \\
\hline Haverhill loam (expected) & $y=17.9+48.1 /\left(1+[x / 32.6]^{1.1}\right.$ & 0.967 \\
\hline (observed) & $y=18.0+47.4 /\left(1+[x / 102.7]^{1.0}\right.$ & 0.920 \\
\hline Haverhill clay loam (expected) & $y=30.0+34.4 /\left(1+[x / 73.9]^{3.1}\right.$ & 0.915 \\
\hline (observed) & $y=38.4+27.0 /\left(1+[x / 82.5]^{6.1}\right.$ & 0.985 \\
\hline
\end{tabular}


Table 3. Multiple regression analysis for pyroxasulfone $\mathrm{GR}_{50}$ values (concentrations corresponding to $50 \%$ inhibition of sugar beet length) and selected soil characteristics

\begin{tabular}{lccc}
\hline \multicolumn{1}{c}{ Model } & Coefficient $^{a)}$ & Standard error & $p$ value ${ }^{b)}$ \\
\hline Constant & 63.6 & 50.5 & 0.234 \\
Organic carbon & 38.8 & 8.7 & 0.001 \\
$\quad$ (\%) & & & \\
Soil pH & -9.3 & 7.1 & 0.218 \\
Clay (\%) & -0.2 & 0.5 & 0.759
\end{tabular}

a) Equation $\mathrm{y}=63.6+38.8 \times \mathrm{OC}(\%)-9.3 \times$ soil $\mathrm{pH}-0.2 \times$ clay $(\%)$; $\mathrm{R}^{2}=0.806 ; \mathrm{F}=15.227 .{ }^{b}$ Significance.

tively. Because sugar beet inhibition was more reproducible than that of canola and oriental mustard as evidenced by the smallest standard deviation, sugar beet was selected for further testing to enhance plant response to pyroxasulfone.

Shoot length inhibition of sugar beet grown for up to 8 days in response to $92 \mu \mathrm{g}$ a.i. $/ \mathrm{kg}$ pyroxasulfone was higher than root length inhibition at each growth period (Fig. 2). Shoot length inhibition increased up to 7 days, and growing plants longer than 7 days did not significantly improve shoot length inhibition detection. Therefore, measuring shoot length inhibition of sugar beet after 7 days was selected for the use in a laboratory bioassay for determination of pyroxasulfone in soil.

\section{Pyroxasulfone bioactivity in soil}

Pyroxasulfone bioactivity evaluated by the 7-day sugar beet shoot length inhibition bioassay varied among the investigated soils (Fig. 3). The $\mathrm{GR}_{50}$ values that were estimated from the dose-response curves ranged from 32.5 to $130 \mu \mathrm{g} / \mathrm{kg}$ (Table 2) with higher $\mathrm{GR}_{50}$ values indicating decreased bioactivity of the herbicide in soil. Multiple regression analysis using organic carbon content (\%), soil $\mathrm{pH}$ and clay content (\%) as independent variables and $\mathrm{GR}_{50}$ as a dependent variable, showed that organic carbon content (\%) was a significant predictor of pyroxasulfone bioactivity in prairie soils (Table 3 ). This demonstrated that increased pyroxasulfone adsorption to organic matter decreased pyroxasulfone bioactivity and subsequently might reduce pyroxasulfone efficacy. These results agree with the findings reported for soils from Australia, ${ }^{4)}$ the United States, ${ }^{1)}$ and Canada ${ }^{8)}$ where higher pyroxasulfone application rates were required to achieve effective weed control in soils containing higher levels of organic matter. Organic matter is colloidal in nature with a reactive surface capable of binding herbicide molecules, and consequently lowering the bioavailable herbicide concentration which has been shown for numerous herbicides. ${ }^{22-26)}$

\section{Effect of soil $p H$ on pyroxasulfone bioactivity}

The soils used in the evaluation of pyroxasulfone bioactivity described above had a broad range of organic carbon content (Table 1) that might have hindered revealing the effect of soil $\mathrm{pH}$ on pyroxasulfone bioactivity. Therefore, the effect of soil $\mathrm{pH}$ on pyroxasulfone bioactivity was examined separately after altering the natural soil $\mathrm{pH}$. Alkalization and acidification yielded differ-
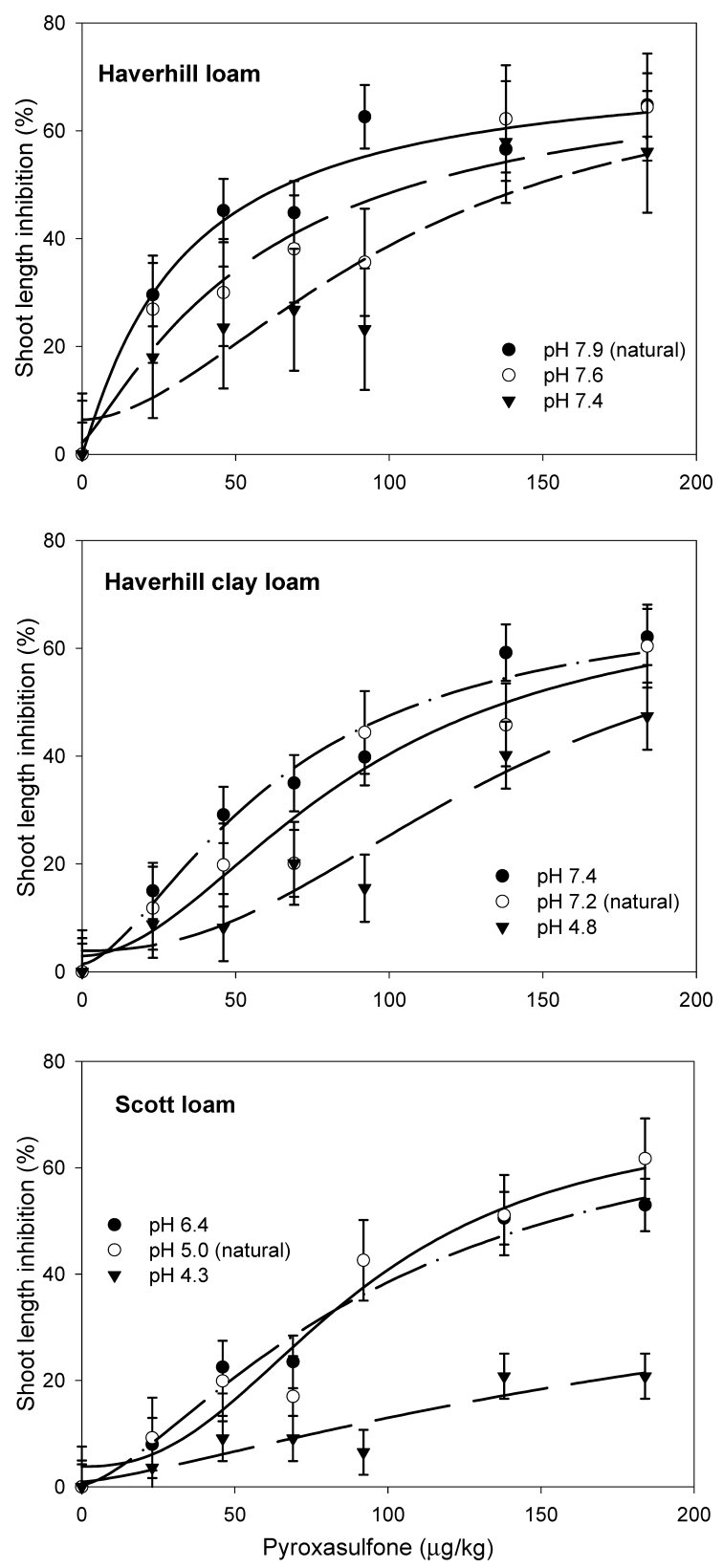

Fig. 4. Effect of soil $\mathrm{pH}$ on pyroxasulfone bioactivity in prairie soils determined by the 7-day sugar beet shoot length bioassay; each data point represents mean \pm standard error; estimated equations are listed in Table 2.

ent increments in soil $\mathrm{pH}$ above and below the natural $\mathrm{pH}$ due to differences in buffering capacity of the soils. Alkalization with $0.2 \mathrm{~g}$ of $\mathrm{CaCO}_{3}$ per $50 \mathrm{~g}$ of soil raised $\mathrm{pH}$ from 7.2 to 7.4 and from 5.0 to 6.4 in Haverhill clay loam and Scott loam, respectively, and did not increase soil pH in Haverhill loam as this soil had relatively high carbonate content and natural $\mathrm{pH}$ (Table 1). Acidification with $0.5 \mathrm{~mL}$ of $1 \mathrm{M} \mathrm{HCl}$ per $50 \mathrm{~g}$ of soil lowered $\mathrm{pH}$ from 7.9 to 7.6, from 7.2 to 4.8 and from 5.0 to 4.3 in Haverhill loam, Haverhill clay loam and Scott loam, respectively. Further acidification of Haverhill loam with $1 \mathrm{~mL}$ of $1 \mathrm{M} \mathrm{HCl}$ per $50 \mathrm{~g}$ of soil lowered $\mathrm{pH}$ of this soil to 7.4 . 
Table 4. Multiple regression analysis for pyroxasulfone dissipation half-lives and selected soil characteristics

\begin{tabular}{lccc}
\hline \multicolumn{1}{r}{ Model } & Coefficient $^{a)}$ & Standard error & $p$ value $^{b)}$ \\
\hline Constant & 164.7 & 26.3 & 0.001 \\
Organic carbon (\%) & -10.8 & 5.5 & 0.034 \\
Soil pH & -11.9 & 3.7 & 0.008 \\
Clay (\%) & -0.4 & 0.3 & 0.196 \\
\hline
\end{tabular}

a) Equation $\mathrm{y}=164.7-10.8 \times \mathrm{OC}(\%)-11.9 \times$ soil $\mathrm{pH}-0.4 \times$ clay $(\%) ; \mathrm{R}^{2}=0.851 ; \mathrm{F}=20.887 .{ }^{b)}$ Significance.

Sugar beet shoot length inhibition was reduced in acidified soils (Fig. 4), demonstrating that pyroxasulfone was less available to plants at lower soil $\mathrm{pH}$. Alkalization increased sugar beet shoot length inhibition in Haverhill loam but did not change sugar beet response in Scott loam (Fig. 4,) indicating that the effect of soil $\mathrm{pH}$ on pyroxasulfone bioactivity could vary with soil type. The $\mathrm{GR}_{50}$ values (Table 2) were correlated with soil $\mathrm{pH}$ in Haverhill loam $\left(\mathrm{R}^{2}=0.96\right)$ and in Haverhill clay loam $\left(\mathrm{R}^{2}=0.93\right)$ but not in Scott loam $\left(\mathrm{R}^{2}=0.52\right)$. These results demonstrated that pyroxasulfone bioactivity is generally sensitive to changes in soil $\mathrm{pH}$ and that pyroxasulfone may be less efficacious in soils of lower $\mathrm{pH}$.

Usually soil pH affects both the dissociation of herbicide molecules and the charges of the organic matter and clay colloids. Pyroxasulfone molecule is not acidic because it does not contain dissociable hydrogen ${ }^{8)}$ (Fig. 1). Therefore, the effect of soil $\mathrm{pH}$ on pyroxasulfone bioactivity could be primarily related to the change in ionic charges on soil colloids. As soil pH decreases, there are fewer negative charges on organic and clay surfaces. ${ }^{27)}$ Typically, this results in greater sorption of herbicides, and subsequently in reduced concentration of bioavailable herbicide in soil solution. ${ }^{25,26,28-30)}$

\section{Pyroxasulfone dissipation under laboratory conditions}

Pyroxasulfone dissipation differed among the investigated soils (Fig. 5); the estimated half-lives ranged from 16 to 69 days and are comparable to reported half-lives from the literature. ${ }^{8)}$ Multiple regression analysis using organic carbon content (\%), soil $\mathrm{pH}$ and clay content (\%) as independent variables and half-live as a dependent variable, showed that organic carbon content (\%) and soil $\mathrm{pH}$ were significant in affecting pyroxasulfone half-life in prairie soils (Table 4). Pyroxasulfone dissipation half-life was shorter when either organic carbon content or soil $\mathrm{pH}$ increased. Typically, high organic matter may either slow down herbicide dissipation by adsorption of a herbicide or may increase the rate of dissipation by providing an environment of enhanced microbial activity. ${ }^{31)}$ Because dissipation was faster in soils of high organic matter, it is therefore possible that the microbial activity associated with organic matter played an important role in pyroxasulfone degradation. However, the mechanism of pyroxasulfone degradation in soil was not investigated in this study since the objective was only to evaluate pyroxasulfone persistence in prairie soils. The more rapid pyroxasulfone dissipation at high soil $\mathrm{pH}$ was potentially related to increased pyroxasulfone bioactivity in soils with raised $\mathrm{pH}$ (see above), and consequently

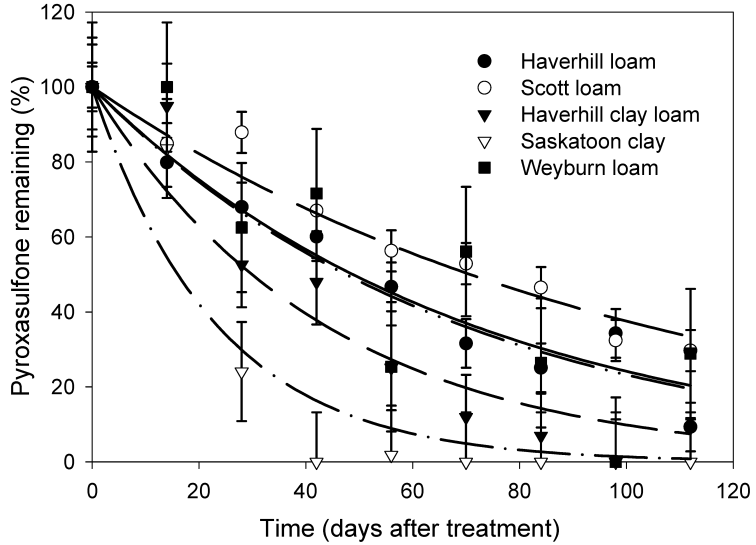

Fig. 5. Pyroxasulfone dissipation determined by the 7 -day sugar beet shoot length bioassay in prairie soils under laboratory conditions of $25^{\circ} \mathrm{C}$ and moisture content of $85 \%$ field capacity: Haverhill loam, $k=0.015 /$ day, $\mathrm{T}_{1 / 2}=49$ days; Scott loam, $k=0.010 /$ day, $\mathrm{T}_{1 / 2}=69$ days; Haverhill clay loam, $k=0.023 /$ day, $\mathrm{T}_{1 / 2}=30$ days; Sutherland clay, $k=0.043 /$ day, $\mathrm{T}_{1 / 2}=16$ days; Weyburn loam, $k=0.014 /$ day, $\mathrm{T}_{1 / 2}=48$ days; each data point represents mean \pm standard error.

increased pyroxasulfone concentration available in soil solution for decomposition. The results of this study showed that the rate of pyroxasulfone dissipation in prairie soils varied with soil type and was more rapid in soils of high organic matter and of high soil $\mathrm{pH}$.

\section{Pyroxasulfone and sulfentrazone interactions}

The expected and observed dose-response curves obtained by measuring shoot length inhibition of sugar beet in response to combined pyroxasulfone and sulfentrazone in two soils are presented in Fig. 6. In Haverhill loam the expected shoot length inhibition was higher (at 0.05 significance level) than the observed inhibition demonstrating that the interaction between pyroxasulfone and sulfentrazone was antagonistic in this soil. In Haverhill clay loam the expected and observed values were not different indicating that the combined effect of pyroxasulfone and sulfentrazone was additive in this soil. In an antagonistic interaction the efficacy of the combined herbicides is reduced and consequently may result in decreased weed control, while in an additive interaction the efficacy is the sum activity of the combined herbicides.

Using herbicides with different mode of action either applied as pre-mixed combinations or applied in rotation reduces problems related to weed resistance and consequently improves 

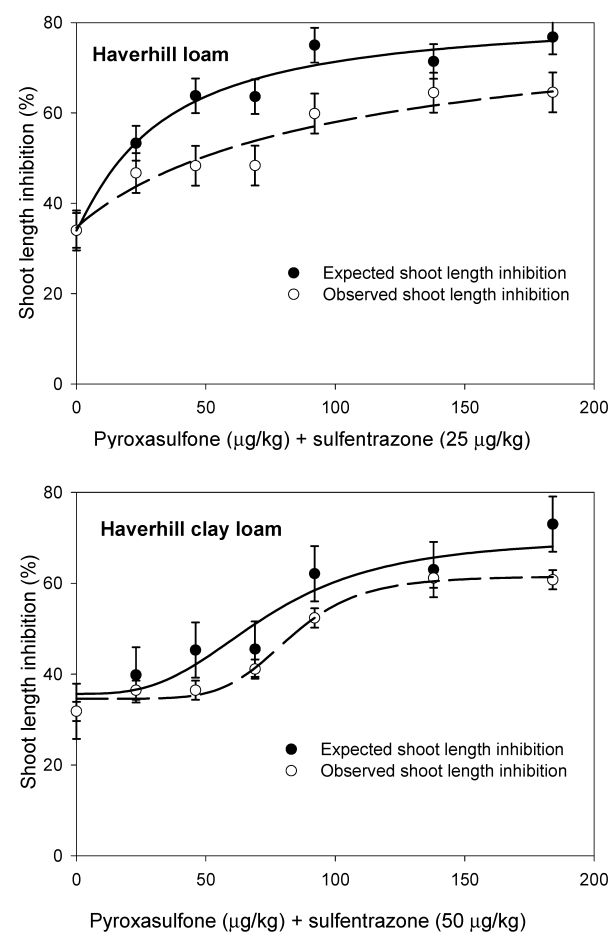

Fig. 6. Dose-response curves for pyroxasulfone in combination with sulfentrazone determined by the 7-day sugar beet shoot length bioassay; each data point represents mean \pm standard error; estimated equations are listed in Table 2.

weed control. However, combinations of herbicides are generally chosen to broaden the spectrum of weed control without prior knowledge of the possible interactions between herbicides. ${ }^{21)}$ It has been reported that weed control with mixtures of pyroxasulfone and sulfentrazone in sunflower production across the Great Plains of the United States generally resulted in additive interactions between these two herbicides, ${ }^{6)}$ but antagonism was also observed with some plant species. ${ }^{13)}$ This study using sugar beet as a bioindicator plant showed that the interactions between pyroxasulfone and sufentrazone may be either antagonistic or additive and that the nature of these interactions could be soildependent.

\section{Acknowledgements}

Financial support of Canada Pulse Science Cluster and FMC Corporation Canada is gratefully acknowledged.

\section{References}

1) S. Z. Knezevic, A. Datta, J. Scott and P. J. Porpiglia: Weed Technol. 23, 34-39 (2009).

2) P. W. Geier, P. W. Stahlman and J. C. Frihauf: Weed Technol. 20, 622626 (2006).

3) S. R. Sikkema, N. Soltani, P. H. Sikkema and D. E. Robinson:
HortScience 43, 170-172 (2008).

4) M. J. Walsh, T. M. Fowler, B. Crowe, T. Ambe and S. B. Powles: Weed Technol. 25, 30-37 (2011).

5) http://www.valent.com/agriculture/products/fierce/upload/2011FIE-2001-Fierce-TIB.pdf (Accessed August 2013)

6) B. L. S. Olson, R. K. Zollinger, C. R. Thompson, D. E. Peterson, B. Jenks, M. Moechnig and P. W. Stahlman: Weed Technol. 25, 217-221 (2011).

7) Y. Tanetani, K. Kaku, K. Kawai, T. Fujioka and T. Shimizu: Pestic. Biochem. Physiol. 95, 47-55 (2009).

8) http://publications.gc.ca/collections/collection_2012/sc-hc/ H113-9-2012-20-eng.pdf (Accessed August 2013)

9) http://www.fmccrop.com/grower/Products/Herbicides/Anthem.aspx (Accessed August 2013)

10) http://www.fmccrop.com/grower/Products/Herbicides/AnthemATZ.aspx (Accessed August 2013)

11) G. L. Steele, P. J. Porpiglia and J. M. Chandler: Weed Technol. 19, 866869 (2005).

12) S. R. King, R. L. Ritter, E. S. Hagood Jr. and H. Menbere: Weed Technol. 21, 578-582 (2007).

13) http://www.sunflowernsa.com/uploads/resources/214/zollinger_ kih485_09.pdf (Accessed August 2013)

14) E. N. Johnson, C. A. Gampe, B. L. Beres, W. M. Hamman, K. Coles and M. Gretzinger: Proceedings of the Western Society of Weed Science Annual Meeting, p. 38, 2013.

15) A. M. Szmigielski, J. J. Schoenau, A. Irvine and B. Schilling: Commun. Soil Sci. Plant Anal. 39, 413-420 (2008).

16) K. E. M. Groves and R. K. Foster: Weed Sci. 33, 825-828 (1985).

17) S. S. Seefeldt, J. E. Jensen and E. P. Fuerst: Weed Technol. 9, 218-227 (1995).

18) A. Walker and P. A. Brown: Bull. Environ. Contam. Toxicol. 30, 365$372(1983)$

19) http://www.intechopen.com/books/herbicides-environmentalimpact-studies-and-management-approaches/use-of-sugar-beetas-a-bioindicator-plant-for-detection-of-flucarbazone-andsulfentrazone-herbicides (Accessed August 2013)

20) S. R. Colby: Weeds 15, 20-22 (1967).

21) J. Zhang, A. S. Hamill and S. E. Weaver: Weed Technol. 9, 86-90 (1995).

22) S. K. Papiernik, W. C. Koskinen and B. L. Barber: J. Agric. Food Chem. 60, 10936-10941 (2012).

23) R. Eliason, J. J. Schoenau, A. M. Szmigielski and W. M. Laverty: Weed Sci. 52, 857-862 (2004)

24) E. Morillo, T. Undabeytia, A. Cabrera, J. Villaverde and C. Maqueda: J. Agric. Food Chem. 52, 884-890 (2004).

25) W. Mersie and C. L. Foy: Weed Sci. 33, 564-568 (1985).

26) G. A. Ohmes and T. C. Mueller: Weed Technol. 21, 796-800 (2007).

27) K. A. Renner, W. F. Meggitt and D. Penner: Weed Sci. 36, 78-83 (1988).

28) M. M. Loux and K. D. Reese: Weed Sci. 40, 490-496 (1992).

29) Q. Wang and W. Liu: Soil Sci. 164, 411-416 (1999).

30) T. L. Grey, R. H. Walker, G. R. Wehtje and H. G. Hancock: Weed Sci. 45, 733-738 (1997)

31) A. Walker: Appl. Plant Sci. 5, 94-98 (1991). 